\title{
Learning to "Play the Game as Men Do": How the General Federation of Women's Clubs Brought Political Science to Women
}

Alixandra B. Yanus, High Point University

ABSTRACT Much has been written about efforts to expand women's social, cultural, and political representation, roles, and opportunities. However, as political scientists, we have done little to document the early history of incorporating women into the discipline. This article illustrates how the General Federation of Women's Clubs (GFWC) established the study of politics as an acceptable course of baccalaureate study for women: first, by crafting a model curriculum; second, by advocating for the creation of endowed chairs in political science at women's colleges; and, third, by publishing in scholarly outlets. The GFWC's efforts can be viewed as the first steps to the incorporation of women into the discipline-a question that continues to be the subject of much analysis and consternation by professional associations and the academic community.

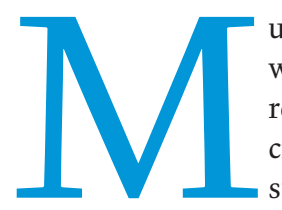
uch has been written about efforts to expand women's social, cultural, and political representation, roles, and opportunities. History credits the activist women of Seneca Falls, the suffrage movement, and organizations including the Woman's Christian Temperance Union for spearheading women's broader civic engagement. We also acknowledge the significance of professional trailblazers and role models, from Jeanette Rankin to Margaret Thatcher to Hillary Clinton. However, as political scientists, we have done little to document the early history of incorporating women into our own discipline. This article illustrates how the work of the General Federation of Women's Clubs (GFWC) established the study of politics as an acceptable course of baccalaureate study for women: first, by crafting a model curriculum; second, by advocating for the creation of endowed chairs in political science at women's colleges; and, third, by publishing in scholarly outlets. The GFWC's efforts can be viewed as the first steps to the incorporation of women in the discipline-a question that continues to be the subject of much analysis and consternation by professional associations and the academic community.

\section{BRINGING WOMEN TO POLITICS}

Women's prominent roles in the moral reform and benevolence movements of the postbellum period and Progressive Era have been well documented. After extending the ideals of Republican

Alixandra B. Yanus is associate professor of political science at High Point University. She can be reached at ayanus@highpoint.edu.
Motherhood to their role in the abolition and temperance movements, women began to demand greater social and political rights for themselves, as well as to hold legislators and localgovernment officials to higher moral standards. Most visibly, late-nineteenth-century groups including the Woman's Christian Temperance Union and the National American Woman Suffrage Association used petitions, public speeches, and community organizing to bring about the total prohibition of alcohol and woman suffrage. These movements were united by the logic that women, as guardians of the private sphere, had a right to press government to uphold moral accountability and improve American family life.

Although these associations were politically powerful, they often were marginalized for being too religious, righteous, or radical. Sentiment began to foment for the creation of a new organization representing educated, literary women with substantial economic and social capital, which they believed could be converted into political capital. The catalyst for the creation of this group, which would become the General Federation of Women's Clubs, ${ }^{1}$ came in 1889 . A New York City literary club, Sorosis, organized a conference with delegates from 61 women's organizations from across the country. Among the GFWC's original members were several prominent journalists, including Jennie June Croly and Fanny Fern, who had been denied entry into the all-male New York Press Club. The organization's growth was exponential; what began as 61 clubs grew to more than 600 clubs and 56,000 active members by 1901 , when the GFWC was officially chartered by Congress (GFWC 1901). Soon, the Federation counted among its members and sympathizers many of the most 
revolutionary women of the era: Julia Ward Howe, Jane Addams, Florence Kelly, Josephine Goldmark, and Eleanor Roosevelt.

On its face, the GFWC maintained the appearance of a literary club. At the organization's outset, almost $90 \%$ of the clubs had literary or library departments (Clemens 1997); even as late as 1920, more than $70 \%$ of clubs reported having literary departments. However, the organization's leaders prioritized different goals. As President Sarah Platt Decker asserted in her 1904 address to the Biennial National Convention, "Dante is dead. He has been dead for several centuries, and I think it is time that we dropped the study of his Inferno and turned our attention to our own" (quoted in Sapiro 2006, 151).

Reflecting this charge, clubwomen were actively involved in many of the most important social issues of the day, from child labor to industrial conditions to city sanitation to pure food and drug laws. They strongly advocated for civic improvement in the form of public parks and national conservation and for education, such as the establishment of free kindergartens and rural schools. Equally important, clubwomen often worked with local, state, and national leaders to secure the creation of and representation on formal government bodies related to these issues. As a sign of their influence, one Washington state legislator observed, "This is fast becoming a government of the women, for the women's views, and by the women's clubs....The men do the voting and elect us to these positions, while the women assume the duty afterward of telling us what they want us to do" (GFWC 1906, 203).

By 1903, the GFWC's leadership-working in cooperation with the American Institute of Instruction and the Daughters of the American Revolution-began to question how the education of women could be shifted to focus on better equipping them to engage in "more practical" matters, including civics (GFWC 1906, 20o). Leaders of the GFWC's education department argued that women needed to be trained to participate in their communities in the same way that they were schooled in the arts of home economics and family sciences. To this end, at its 1906 Biennial, the group urged civics education in public schools and the creation of a model curriculum addressing national, state, and municipal government. Although no formal curriculum was crafted, instructional models used in Philadelphia, Chicago, and Batavia, New York, were held up as exemplary illustrations. no study of the principles on which our country rests, no comprehension of the far-reaching effects of premature legislation, and no understanding of the peculiar and delicate structure of our Federal Republic. (GFWC 1910, 381-82)

Although the GFWC acknowledged that not all women required baccalaureate degrees in law or the social sciences to effectively press the government for social reforms, the organization nonetheless called for the expansion of collegiate education in these areas to open doors for the women who would serve as the next generation of movement leaders. In particular, it asserted the importance of gender integration in elite colleges and law schools. "When the intellect of women is trained in the same schools as her brothers," the GFWC's Biennial Report observed, "her judgment developed by the same tests, her social vision extended to the same horizon, her co-operation based upon equal privilege and equal knowledge, then will her influence be co-equal in the field of legislation" (GFWC 1910, 386).

For the overall membership, the GFWC also called for the development of a course of study to focus on the fundamental laws of the land so that individuals-and particularly women-would be better equipped for engaged citizenship. Relating the activity to the numerous other courses of study in history, literature, music, and art already utilized by clubwomen, leaders called for the acquisition of a "general knowledge of that science which transcends all others in its application to human affairs" (GFWC 1910, 383).

These efforts to broadly educate women in the still-emerging discipline of political science gained greater urgency beginning in 1912, with the presidency of Mrs. Philip (Eva Perry) North Moore. ${ }^{2}$ In addition to her service to the GFWC, Mrs. Moore was an alumnus and member of the Board of Trustees of Vassar College, and she was active throughout her life in the suffrage, education, and peace movements. She worked with President William Howard Taft in the Panama Canal Zone and served on the Women's Commission of the Council on National Defense. In her 1912 presidential address, she identified "Political Science" as a key "Plan of Work" for the GFWC's education department during her tenure (GFWC 1912, 73).

By all accounts, Mrs. Moore put her full support behind this effort; it would not be exaggeration to state that her leadership makes her one of the foremothers of women in political science.

\section{Leaders of the GFWC's education department argued that women needed to be trained to participate in their communities in the same way that they were schooled in the arts of home economics and family sciences.}

\section{BRINGING POLITICS TO WOMEN}

By the 1910 Biennial, GFWC leaders had increased the urgency of their call to educate women for participation in the political movements of the day. This, the clubwomen contended, was a logical extension of the Federation's education work in other sectors:

We no longer expect a young girl to assume control of her home and succeed in its management without previous training; we do not put a pattern in the hands of our daughters and require them to make their gowns without some preliminary instructions; and yet we presume to enter the broad realm of law and legislation with no training,
Most visibly within the academy, she used her position on the Vassar Board of Trustees to encourage the university to establish the first chair in political science at a women's college. The position, established after careful study by President James Monroe Taylor and the Committee on Faculty and Studies, was officially sanctioned at the Board of Trustees meeting on February 13, 1913. The Board agreed that the position should be established "at as early a date as may be possible consistently with our financial condition" (Vassar College Archives 1913). By meeting's end, Mrs. Frederick Ferris Thompson had agreed to grant the necessary endowment of \$75,000-equivalent to nearly \$2 million in 2018 dollars (GFWC 1914; Vassar College Archives 1913).3 In addition 
to teaching, among the early responsibilities of this faculty member was overseeing a series of six lectures on the principles of law, covering topics such as contracts, property, and wills, which were "open to students of the college but without required attendance" (Vassar College Archives 1915).

Moore's Political Science Committee also was tasked with developing a model curriculum to be used in women's colleges as well as by interested clubs within the GFWC. The initiative was led by Helen Varick Boswell, who had a long history of involvement in the Federation as well as within the Women's National Republican Association and the Republican Party (Freeman 2008). Because the GFWC's primary goal was to create educated citizens and activists, the curriculum heavily emphasized the American system. It included instructional units on national government, including the "administrative," legislative, and judicial branches, as well as national bureaus and "delegate bodies" within the major political parties. The model curriculum also emphasized the importance of state governments, particularly governors and legislatures. It also addressed several significant public policies, including child and prison labor, agricultural credits, tariffs, and woman suffrage. Finally, the model curriculum included limited instruction on municipal government, including townships and counties. It was accompanied by a well-curated bibliography, which included classical political science texts by Charles Beard and Woodrow Wilson as well as policy briefings by activists (and GFWC members) such as Goldmark and Addams (GFWC 1914, 137-40).

In its first two years, more than 300 clubs in 29 states used the course of study (GFWC 1914). By the 1916 Biennial, the Federation's political science department reported that its efforts "had been justified by results." The widespread adoption of the model curriculum both expanded women's study of politics and leadership and prompted an increase in tangible political activities, such as encouraging state conventions and clubs to pass suffrage resolutions and creating and circulating literature on tariff legislation (GFWC 1916, 344).

\section{PRACTICAL IMPACT}

Through drafting a model curriculum, establishing political science as an appropriate and even necessary field of study at women's colleges, and making inroads for members' written work to be published in social-scientific outlets, the GFWC helped women to breach the walls of the academy. The organization's efforts and achievements built several important ladders that generations of women academics could climb in the pursuit of social and political change in a world dominated by elite-college-educated men with degrees in fields such as law, political science, and sociology (see, e.g., Skocpol 1995). Although many of these institutions once excluded women, establishing equivalent curricular programs at the most prestigious women's institutions was an essential first step. As Eleanor Roosevelt aptly summarized, "Women must learn to Play the Game as Men Do...If women believe they have a right and duty in political life today, they must learn to talk the language of men. They must master not only the phraseology, but also understand the machinery which men have built up through years of practical experience. Against the men bosses, there must be women who can talk as equals" (quoted in Clemens 1997, 232-33).

In addition to training women to participate in politics, the GFWC's efforts laid the groundwork for progress in the discipline. Departments and faculty that focused on government, politics, and political science were added at other women's colleges throughout the next 30 years. ${ }^{5}$ Moreover, although the growth of women in the profession was slow, it was substantial enough by 1969 that the American Political Science Association (APSA) built on the momentum of the women's movement to establish a Committee on the Status of Women. This committee, with the Committee on the Status of Blacks in the Profession, was among APSA's first formal commissions to address diversity and inclusion in the profession (APSA 2011). In the years following its creation, the percentage of PhDs in political science awarded to women doubled from $10 \%$ in 1970 to almost $20 \%$ in the 1980 s (APSA 2004).

\section{The widespread adoption of the model curriculum both expanded women's study of politics and leadership and prompted an increase in tangible political activities, such as encouraging state conventions and clubs to pass suffrage resolutions and creating and circulating literature on tarifflegislation (GFWC 1916, 344).}

Although the committee's efforts were waylaid by emphasis on the war and armistice during the next two Biennials, the GFWC's efforts did not go unnoticed in the academy. In fact, Boswell's work was published in the Annals of the American Academy of Political and Social Sciences in 1913 and 1916. In 1913, Boswell (1913) authored an entry analyzing the GFWC's work on women and prison labor, connecting the club's efforts to earlier policies employed in England, France, and Germany. Her 1916 entry focused on the organization's work in the "new citizenship movement" - that is, efforts to teach immigrants about American culture with the ultimate goal of "Americanization" or cultural assimilation (Boswell 1916). It perhaps goes without saying that this academic recognition was accorded to few of Boswell's female contemporaries. 4
Also in 1969, women political scientists formed the independent, non-profit Women's Caucus for Political Science. With its regional affiliates, the organization was instrumental in advocating for the relocation of political science conferences away from states that had not ratified the Equal Rights Amendment in the 1970s and early 1980 , as well as in establishing a legal defense fund for women in the discipline (Women's Caucus for Political Science 2018).

Today, women receive slightly more than $40 \%$ of baccalaureate degrees in political science and a similar percentage of $\mathrm{PhDs}$ (Brown et al. 2017; National Center for Education Statistics 2013). ${ }^{6}$ Whereas women also comprise nearly half of assistant professors, they are overrepresented among term faculty and underrepresented at higher ranks and when compared to other social sciences (Brown et al. 2017). As this evidence suggests, there is still substantial 
progress to be made, particularly on issues such as the leaky pipeline, institutional climates, and implicit citation biases (APSA 2004; Beaulieu et al. 2016). However, all modern women political scientists-and the discipline as a whole-owe a debt of gratitude to the women of the GFWC's political science department; in particular, the advocacy of Mrs. Frederick North (Eva Perry) Morris and Helen Varick Boswell, who had the audacity to believe that "education for citizenship is as necessary for the girls as for the boys" (GFWC 1914, 136).

\section{NOTES}

1. As Clemens (1997) noted in The People's Lobby, referring to themselves as "clubwomen" was in itself a subversive activity. She quoted one early member as saying that "club" was "claimed to be an escape from the old special titles used for women's unions, in church, and other activities, while inclusive of al these within its membership, and therefore significant of a new departure in fellowship and effort. It was a 'woman's club'-an unknown quantity heretofore and therefore novel" (quoted in Clemens 1997, 54).

2. Throughout the article, I refer to Mrs. Moore by her married and/or husband's name because this was her style in GFWC correspondence. The decision regarding whether to use their husband's name as well as the prefix "Mrs." was a contentious issue among the club's membership. Ultimately, the Federation decided to allow individual discretion about this choice.

3. Mrs. Thompson was herself an alumnus and member of the Board of Trustees. The chair was named for her husband, Frederick Ferris Thompson, a Williams College alumni and member of the Vassar Board of Trustees from 1885 to 1899 (Vassar Quarterly 1984). Today, the chair is held by Dr. Katherine Hite.

4. Several other early twentieth century editions of The Annals also include entries on GFWC initiatives.

5. Several examples are illustrative: publicly available Bryn Mawr College catalogs list an instructor in politics as early as 1918 and a professor of political science as early as 1921 (Bryn Mawr College 1918; 1921). Mount Holyoke College added a politics department in 1931 (Mount Holyoke College Archives N.D.). At Wellesley College, courses in politics had been taught within the history and economics departments as early as 1883 . The college hired its first full-time political scientist in 1922; an independent department of political science was established in 1940 (Wellesley College Department of Political Science 2015)

6. Importantly, the percentage of $\mathrm{PhDs}$ granted to women has stalled since at least 2002, with little progress being made at the highest ranks of the professorate (APSA 2004). In 2014, for example, the National Science Foundation reported that women still comprised only about $20 \%$ of full professors in political science (Brown et al. 2017).

\section{REFERENCES}

American Political Science Association. 2004. Women's Advancement in Political Science: A Report of the Workshop on the Advancement of Women in Academic Political Science in the United States. Washington, DC: American Political Science Association.

American Political Science Association. 2011. Political Science in the 21st Century: Report of the Task Force on Political Science in the 21st Century. Washington, DC: American Political Science Association.
Beaulieu, Emily, et al. 2016. "Here's a List of Smart Women Political Scientists. They Know Stuff, Too.” Washington Post, February 11. Available at www.washingtonpost. com/news/monkey-cage/wp/2016/o2/11/heres-a-list-of-smart-women-politicalscientists-they-know-stuff-too.

Boswell, Helen Varick. 1913. "Women and Prison Labor." Annals of the American Academy of Political and Social Science 46: 17-12.

Boswell, Helen Varick. 1916. "Promoting Americanization." Annals of the American Academy of Political and Social Science 49: 204-9.

Brown, Nadia, et al. 2017. "How Are Women Political Scientists Doing? A Report from the APSA Committee for the Status of Women in the Profession and the Thelen Presidential Taskforce." Comparative Newsletter 27 (1): 81-83.

Bryn Mawr College. 1918. Bryn Mawr College Calendar. Bryn Mawr, PA: Bryn Mawr College.

Bryn Mawr College. 1921. Bryn Mawr College Calendar. Bryn Mawr, PA: Bryn Mawr College.

Clemens, Elisabeth Stephanie. 1997. The People's Lobby. Chicago: University of Chicago Press.

Freeman, Jo. 2008. We Will Be Heard: Women's Struggles for Political Power in the United States. Lanham, MD: Rowman \& Littlefield.

General Federation of Women's Clubs. 1901. List of Officers and Directors, Federation Secretaries and Committees, State Federations and List of Federated Clubs of GFWC. Washington, DC: General Federation of Women's Clubs.

General Federation of Women's Clubs. 1906. Report of the Eighth Biennial Convention. St. Paul, MN.

General Federation of Women's Clubs. 1910. Report of the Tenth Biennial Convention Cincinnati, $\mathrm{OH}$.

General Federation of Women's Clubs. 1912. Report of the Eleventh Biennial Convention. San Francisco.

General Federation of Women's Clubs. 1914. Report of the Twelfth Biennial Convention. Chicago.

General Federation of Women's Clubs. 1916. Report of the Thirteenth Biennial Convention. New York.

Mount Holyoke College Archives and Special Collections. N.D. "Politics Department." Available at http://asteria.fivecolleges.edu/findaids/mountholyoke/mshm687_ main.html.

National Center for Education Statistics. 2013. Digest of Educational Statistics. Available at https://nces.ed.gov/programs/digest/d13/tables/dt13_318.30.asp.

Sapiro, Virginia. 2006. "Gender, Social Capital, and Politics.” In Gender and Social Capital, ed. Brenda O'Neill and Elisabeth Gidengil, 151. New York: Routledge.

Skocpol, Theda. 1995. Protecting Soldiers and Mothers. Cambridge, MA: Harvard University Press.

Vassar College Archives. 1913. "Trustee Minutes, 13 February 1913."

Vassar College Archives. 1915. "Trustee Minutes, 8 June 1915."

Vassar Quarterly. 1984. "Letters." Vassar Quarterly 8o (4): 2-3.

Wellesley College Department of Political Science. 2015. "History of the Department." Available at www.wellesley.edu/politicalscience/historyof-the-department.

Women's Caucus for Political Science. 2018. "Welcome." Available at https:// womenscaucusforpoliticalscience.org. 